\title{
Metabolic, productive and reproductive responses to postpartum short-term supplementation in primiparous beef cows
}

\author{
Ana Laura Astessiano1, Raquel Pérez-Clariget ${ }^{1}$, Ana Carolina Espasandín", \\ Carlos López-Mazz', Pablo Soca1 ${ }^{1}$, Mariana Carriquiry ${ }^{1}$
}

${ }^{1}$ Facultad de Agronomía, Universidad de la República (UdelaR), Avenida Garzón 780, Montevideo, Uruguay.

\begin{abstract}
The objective of this study was to evaluate the effect of a short-term supplementation with rice bran ( $2 \mathrm{~kg} / \mathrm{cows} /$ day $)$ on the endocrine and metabolic profiles and hepatic gene expression, associated with the reproductive response in beef cows in grazing conditions. Thirty-eight primiparous beef cows (Hereford, Angus and Hereford $\times$ Angus) were used in a randomized block design according to genotype, calving date and body condition score at calving (BCS). At $64 \pm 14$ days postpartum (day 0 of the experiment), cows were assigned to two nutritional treatments: i) control, grazing native pastures $(\mathrm{CON}, \mathrm{n}=19)$ and ii) supplemented (SUP, $\mathrm{n}=19)$ for 21 days (days 1 to 21 of the experiment). Blood samples were collected at 0,7 and 22 days and liver biopsies were obtained at day 22 to determine the abundance of mRNA of growth hormone receptor (GHR), insulin-like growth factor -I (IGF1), and its binding proteins -2 and -3 (IGFBP2 and IGFBP3), and insulin receptor (INSR) using SYBR-Green real-time RT- PCR with hypoxanthine phosphoribosyltransferase as endogenous control. Short-term supplementation with rice bran did not modify either cow BCS or BW, or calf BW or average daily gain. However, it decreased by 11 days the length of postpartum anestrus of primiparous cows in grazing conditions, associated with increased concentrations of glucose and insulin, and reduced hepatic expression of IGFBP2 mRNA at the end of the experimental period.
\end{abstract}

Key Words: GH-IGFI axis, metabolism, mRNA

\section{Introduction}

In extensive systems of beef production in Uruguay, variations in the quantity and quality of native pasture determine fluctuations in cow nutrient supply, which cause animals to transit during periods of negative energy balance. Thus, concentrations of metabolic hormones associated with reproduction are affected, increasing the duration of postpartum anestrus (Lucy, 2003; Hess et al., 2005).

The hypothalamic-pituitary-gonadal axis plays a central role in the regulation of reproduction, but it requires integrating peripheral signals (metabolites and hormones) for its correct function. The liver plays a key role in the synthesis of glucose and oxidation of non-esterified fatty acids (NEFA) (Drackley et al., 2001) and is the main organ of synthesis of insulinlike growth factor type I (IGF-I) in response to the union of growth hormone $(\mathrm{GH})$ with its receptor (GHR) (Bauman, 2000). Changes in the concentrations of GH and/or changes in circulating concentrations of glucose, NEFA and insulin or IGF-I are indicators of energy availability and animal metabolic status (Hess et al., 2005; Lucy et al., 2009).

The duration of postpartum anestrus is the main cause of reproductive inefficiency in beef cows (Short et al., 1990) and has been associated with reduced blood concentrations

Received October 10, 2011 and accepted November 7, 2012. Corresponding author: lauaste@gmail.com of insulin, IGF-I and/or IGFBP-2 in beef and dairy cows (Robert et al., 1997; Meikle et al., 2004; Sinclair, 2008).

The use of short-term energy supplementation (flushing) is a common practice in sheep production as it significantly improves reproductive performance (Nottle et al., 1997). Although the response to flushing is more variable in beef cattle (Lake et al., 2005; Mulliniks et al., 2008; Wetterman et al., 1986), it has been demonstrated that the use of flushing, prior to or during mating, in nutrient restrictive conditions, increased pregnancy rate in primiparous cows with moderate or low body condition score (BCS) during the mating season (Pérez-Clariget et al., 2007; Soca et al., 2008). However, the physiological and molecular mechanisms responsible for the cow metabolic status and reproductiveproductive responses to flushing are not yet elucidated.

The hypothesis of this work was that a short-term energy supplementation prior to the mating season would decrease days to resumption of ovarian cyclicity in primiparous beef cows in grazing conditions by modifying metabolic signals that impact on the reproductive axis.

The objective of this study was to evaluate the effect of short-term supplementation (flushing) in primiparous beef cows on their metabolic and endocrine profiles, and hepatic expression of genes associated with the GH-IGF-I axis. 


\section{Material and Methods}

The experiment was carried out at the Experimental Station Bernardo Rosengurtt (Cerro Largo, Uruguay; $32^{\circ} \mathrm{S}, 54^{\circ} \mathrm{W}$ ) of School of Agronomy-UdelaR-Uruguay, according to animal procedures approved by the Animal Experimentation Committee (CHEA, UdelaR, Uruguay). Thirty-eight suckled primiparous crossbred beef cows (Hereford, Angus and F1 crosses) with $402 \pm 6.7 \mathrm{~kg}$ of body weight (BW), $4 \pm 0.05$ units of BCS and in anestrus were used. Cows grazed together on a 50 ha native pasture paddock (1388 kg DM/ha, $85 \mathrm{~g} / \mathrm{kg}$ crude protein (CP), $630 \mathrm{~g} / \mathrm{kg}$ neutral detergent fiber (NDF); average of samples collected at the beginning and end of the experiment), with good access to water. Cows were grouped by the following criteria: genetic group, calving date and BCS at calving. Nutritional treatments started at $64 \pm 14$ days postpartum (onset of nutritional treatment $=$ day 0 ) and were: i) control (CON, $n=19)$; and ii) supplemented (SUP, $\mathrm{n}=19$ ). Cows were supplemented with $2 \mathrm{~kg} / \mathrm{cow} /$ day of whole rice bran $(903 \mathrm{~g} / \mathrm{kg} \mathrm{DM}, 100 \mathrm{~g} / \mathrm{kg} \mathrm{CP}, 90 \mathrm{~g} / \mathrm{kg}$ ether extract (EE), $140 \mathrm{~g} / \mathrm{kg} \mathrm{NDF}$ ) during 21 days (from day 1 to day 21 of experiment). Supplemented animals were taken to the feeders daily in the morning and returned to grazing once they finished eating. The supplement intake was controlled individually; there were no refusals of supplement offered. At the end of the nutritional treatment, cows were naturally mated with bulls (in a $3 \%$ proportion) with previous andrological evaluation (McGowan et al., 1995) during a 75-day period.

Cow BCS was recorded at 0,7 and 22 days (before, during and at the end of the nutritional treatment) according to a scale validate in Uruguay by Vizcarra et al. (1986) (scale 1-8; Vizcarra et al., 1986), as well as cow and calf BW using a digital scale. Blood samples were collected weekly from 7 days before the initiation of the nutritional treatment (day -7) to day 49 of experiment, early in the morning, by jugular venipuncture using $10 \mathrm{~mL}$ Vacutest ${ }^{\circledR}$ tubes (Vacutest Kima, Arzergrande, Italy) with heparin. Refrigerated samples were centrifuged at $2500 \mathrm{X} g$ for 15 minutes, and plasma was stored at $-20{ }^{\circ} \mathrm{C}$ until assayed.

Liver samples $(500 \mathrm{mg}$ ) were obtained on day 22 (end of nutritional treatment) from a subset of 16 animals ( 8 cows/group) at the end of the nutritional treatment (day 23 ) by biopsy using a 14-gauge biopsy needle (Tru-Core ${ }^{\circledR}$ II Automatic Biopsy Instrument; Angiotech, Lausanne, Suitzerland) according to procedure described by Astessiano et al. (2012). Liver samples were immediately frozen in liquid nitrogen and stored at $-80{ }^{\circ} \mathrm{C}$ until total RNA was isolated. Presence of corpus luteum (CL) or pregnancy were confirmed by transrectal ultrasonography (Aloka SSD 500 Echo Camera, Overseas Monitor Corp. Ltd., Richmond, $\mathrm{BC}$ with a $5 \mathrm{MHz}$ linear-array transrectal transducer). The device was used at days -7, 0, 22, 49, 77 and 96.

Metabolite and insulin concentrations were measured in samples in a subset of 16 cows at 0,7 and 22 days (before, during and at the end of the nutritional treatment). Nonesterified fatty acids (NEFA), cholesterol, glucose, and urea concentrations were determined by spectrophotometry using commercial kits (Wako NEFA-HR(2), Wako Pure Chemical Industries Ltd., Osaka, Japan; Oxidase/Peroxidase and Biuret, of BioSystems S.A., Barcelona, Spain, respectively). Sample and reagent volumes were adjusted to a 96-well microplate and read on a Multiskan EX (Thermo Scientific, Waltham, MA, USA). All samples were determined in the same metabolite assay. Intra-assay coefficients of variation $(\% \mathrm{CV})$ for low and medium controls were not greater than $12 \%$. Insulin concentrations were quantified by solid-phase radioimmunoassay (RIA) (Coat and Count, Diagnostic Products Co. Los Angeles, CA, USA). All samples were determined in the same assay; the sensitivity was $1.6 \mu \mathrm{IU} / \mathrm{mL}$. The intra-assay $\% \mathrm{CV}$ for low $(2.85 \mu \mathrm{IU} / \mathrm{mL})$, medium $(16 \mu \mathrm{IU} / \mathrm{mL})$ and high $(35.5 \mu \mathrm{IU} / \mathrm{mL})$ controls were 11.3 , 7.7 and $9.2 \%$, respectively.

Concentrations of progesterone (P4) were measured in all cows and samples from day -7 to 49 , using a solidphase RIA (Coat and Count, Diagnostic Products Co). Progesterone concentrations of days -7 and 0 were used to confirm anestrus $(\mathrm{P} 4<0.5 \mathrm{ng} / \mathrm{mL})$. Days of resumption of ovarian cyclicity were considered when plasma P4 increased above the threshold value of $1 \mathrm{ng} / \mathrm{mL}$. The sensitivity was $0.02 \mathrm{ng} / \mathrm{mL}$; the inter- and intra-assay $\% \mathrm{CV}$ for low $(0.6 \mathrm{ng} / \mathrm{mL})$, medium $(2.0 \mathrm{ng} / \mathrm{mL})$ and high $(7.7 \mathrm{ng} / \mathrm{mL}$ ) controls were 8.7 and $8.5 \%, 5.8$ and $7.7 \%$, and 11 and $7.8 \%$, respectively.

Total RNA was isolated using TRIzol ${ }^{\circledR}$ (Invitrogen, Life Technologies, Carlsbad, CA, USA), followed by precipitation with lithium chloride and by DNase-treatment with a DNA-Free ${ }^{\mathrm{TM}}$ Kit (Applied Biosystems/Ambion, Austin, TX, USA). Concentration of RNA was determined by measuring absorbance at $260 \mathrm{~nm}$ (NanoDrop ND1000 Spectrophotometer; Nanodrop Technnologies Inc., Wilmington, DE, USA), and purity and integrity of RNA isolates were assessed from 260/280 and 260/230 absorbance ratios and by electrophoresis in $1 \%$ agarose gel. Isolated RNA was stored at $-80{ }^{\circ} \mathrm{C}$ until analyzed by quantitative real-time PCR.

The SuperScript ${ }^{\circledR}$ III First-Strand Synthesis System kit (Invitrogen) was used to conduct the reverse transcription using random hexamers and $1 \mu \mathrm{g}$ of total RNA as a 
template. The cDNA was stored at $-20^{\circ} \mathrm{C}$ until its use in the real time PCR. Primers (Primer Express Software, Applied Biosystems, Foster City, CA, EUA) designed specifically to amplify cDNA of GHR, IGF1, IGFBP2, IGFBP3, and insulin receptor (INSR) as target genes of interest and for hypoxanthine phosphoribosyltransferase (HPRT) as an endogenous control were used (Table 1).

The gene HPRT had been used before as an endogenous control in tissues from ruminants (Carriquiry et al., 2009; Astessiano et al., 2012) and its expression was determined in the samples of this study and proved to be a good housekeeping gene since there was no variation between treatments.

Abundance of mRNA was determined by real time PCR reactions d using $10 \mu \mathrm{LSYBR}^{\circledR}$ Green mastermix (Quantimix EASY SYG kit, Biotools B\&M Labs, Madrid, Spain), equal amounts (200 nM) of forward and reverse primers (Operon Biotechnologies GmbH., Cologne, Germany) and $3 \mu \mathrm{L}$ diluted cDNA (1:7.5 in RNase/DNase free water) in a final volume of $20 \mu \mathrm{L}$. Samples were analyzed in duplicate in a 72-disk Rotor-GeneTM 6000 (Corbett Life Sciences, Sydney, Australia). Standard amplification conditions were $10 \mathrm{~min}$ at $95^{\circ} \mathrm{C}$ and 40 cycles of $15 \mathrm{~s}$ at $95^{\circ} \mathrm{C}, 45 \mathrm{~s}$ at $60^{\circ} \mathrm{C}$, and $20 \mathrm{~s}$ at $72^{\circ} \mathrm{C}$. For quantification, standard curves $(n=6$ dilutions from $10^{6}$ to $10^{1}$ ) were generated using plasmids that encoded the target and control genes. Linear regressions were used to estimate the number of copies of target and control gene mRNA in the samples and expression of each target gene was normalized to expression of the HPRT control gene (Carriquiry et al., 2009). The efficiency of amplification for mRNA expression of GHR, IGF1, IGFBP2, IGFBP3, INSR and HPRT was 109, 99, 94, 85, 97 and 115\%. Inter and intra-assay CV\% were 1.2 and $3.6 \%$, respectively.

Individual energy intake was estimated using energy requirements (NRC, 2000) of the cow-calf pair (Smit et al.,
2005). Data were analyzed in a randomized block design using the SAS system (Statistical Analysis System, version 9.2). Data on BW, BCS, plasma metabolite and insulin concentrations were analyzed by repeated measures using the MIXED procedure with day of the experiment as the repeated effect, and the AR(1) (first-order autoregressive) as a covariance structure. The Kenward-Rogers procedure was used to adjust the denominator degree of freedom. The model included nutritional treatment, days of experiment, and their interaction as fixed effects, block as random effect, and pretreatment values of BW, BCS, metabolite and insulin concentrations as covariates in their respective data analyses. Impacts of pre-treatment alterations were assessed from a comparison of confidence intervals $(\alpha=0.05)$ between covariate values and post-treatment data. Calf average daily gain and hepatic mRNA expressions were analyzed using the same model without the repeated effect of day of experiment. Days to resumption of ovarian cyclicity, and pregnancy with Poisson and Binomial distributions were analyzed (with log and logit transformations, respectively) with a model that included nutritional treatment as fixed effect using the GENMOD procedure. Correlation coefficients were estimated using the CORR procedure. Data are presented as least square means \pm pooled standard errors.

\section{Results and Discussion}

The estimated energy intake did not differ between treatments. Moreover, supplementation affected neither cow BW nor BCS during the evaluation period $(\mathrm{P}>0.49$, Table 2). These results are in agreement with previous studies in which body reserves were not altered in beef cows supplemented during postpartum, with energy or protein concentrates, for periods shorter than 30 days (Wettemann

Table 1 - Primers used for real time RT-PCR quantification of target and endogenous control genes

\begin{tabular}{|c|c|c|c|c|c|}
\hline Gene & Accesion $\mathrm{N}^{1}$ & & Primer sequence & Length (bp) & Source \\
\hline \multirow[t]{2}{*}{ GHR } & NM_17768 & Sense & TCTGGGAATCCTAAATTCACCAA & 91 & Carriquiry et al. (2009) \\
\hline & & Antisense & CTGTAAACTGTGATTAGCCCCATCT & & \\
\hline \multirow[t]{2}{*}{ IGF1 } & XM_61412 & Sense & CCAGACAGGAATCGTGGATG & 89 & Carriquiry et al. (2009) \\
\hline & & Antisense & ACTTGGCGGGCTTGAGAG & & \\
\hline \multirow[t]{2}{*}{ IGFBP2 } & NM_17455.1 & Sense & ATGCGCCTTCCGGATGA & 83 & Astessiano et al. (2012) \\
\hline & & Antisense & GTTGTACAGGCCATGCTTGTCA & & \\
\hline \multirow[t]{2}{*}{ IGFBP3 } & NM_174556 & Sense & AGCACAGACACCCAGAACTTCT & 86 & Carriquiry et al. (2009) \\
\hline & & Antisense & TTCAGCGTGTCTTCCATTTCC & & \\
\hline \multirow[t]{2}{*}{ INSR } & XM_590552.4 & Sense & CTGAAGCCAAGGCAGATGATATT & 77 & Astessiano et al. (2012) \\
\hline & & Antisense & GCCACATCAAGTGAACAACGTT & & \\
\hline \multirow[t]{2}{*}{ HPRT } & XM_580802 & Sense & TGGAGAAGGTGTTTATTCCTCATG & 105 & Carriquiry et al. (2009) \\
\hline & & Antisense & CACAGAGGGCCACAATGTGA & & \\
\hline
\end{tabular}

GHR - growth hormone receptor; IGF1 - insulin-like growth factor-1; IGFBP2 - IGF binding protein-2; IGFBP3 - IGF binding protein-3; INSR - insulin receptor; HPRT hypoxanthine phosphoribosyltransferase (endogenous control).

${ }^{1}$ GeneBank sequence. 
et al., 1986; Pérez-Clariget et al., 2007; Soca et al., 2007). As described by Moore et al. (1999), these results suggest that at the beginning of the nutritional treatment, forage and energy intakes were enough to meet the requirements for maintenance and production.

Similarly, calf BW and average daily gain during the supplementation period did not differ between treatments $(\mathrm{P}>0.64$, Table 2). Based on the described association between calf average daily gain and cow milk production (Alencar, 1989), these observations would suggest that short-term supplementation with whole rice bran did not affect cow milk production. In contrast, Astessiano et al. (2012) observed that cow BW and BCS, as well as calf BW and average daily gain increased with a short-term increase ( 23 days) of the nutritional plane using native pastures improved with temperate legumes (Lotus subbiflorous cv. Rincón). Differences between the latter and the present study could be due to cow BCS (4.0 vs. 3.6) and days postpartum (64 vs. 48 days) at the beginning of the nutritional treatment as well as characteristics of the feed offered (concentrate vs. pasture). Similarly, Roman et al. (2011) observed an increase in cow BW, BCS and milk production and calf BW in cows supplemented with whole rice bran and pure glycerin for 21 days since 47 days postpartum. The results of the present work (contrary to the findings of Roman et al. (2011) and Astessiano et al. (2012)) suggest changes in cow energy and nutrient partitioning in response to supplementation characteristics (type of supplement, duration, quantity).

Concentrations of NEFA (Figure 1A) that reflect adipose tissue rate of lipolysis (Lucy et al., 2003) were similar between treatments, as they were not affected by nutritional treatment $(\mathrm{P}=0.26)$, remaining at basal concentrations during the experimental period. As described by Ndlovu et al. (2007), decreased concentrations of this metabolite

Table 2 - Production variables and body condition score (BCS) of beef cows and their calves, with (SUP) or without $(\mathrm{CON})$ short-term supplementation during the postpartum period

\begin{tabular}{lcccc}
\hline & \multicolumn{4}{c}{ Nutritional treatment $^{1}$} \\
\cline { 2 - 5 } & CON & SUP & SE & P-value \\
\hline Cows & & & & \\
Estimated energy intake (Mcal/d) & 12.8 & 12.3 & 0.43 & 0.49 \\
BW $(\mathrm{kg})$ & 422 & 405 & 9.40 & 0.20 \\
BCS & 3.80 & 3.75 & 0.07 & 0.35 \\
Calves & & & & \\
BW $(\mathrm{kg})$ & 109 & 105 & 4.20 & 0.51 \\
ADG $(\mathrm{g} / \mathrm{d})$ & 0.83 & 0.83 & 0.06 & 0.98 \\
\hline
\end{tabular}

${ }^{1}$ Control cows grazing native pastures $(\mathrm{CON}, \mathrm{n}=19)$ or supplemented $(\mathrm{SUP}, \mathrm{n}=19)$ for 21 days with $2 \mathrm{~kg}$ /animal/day of whole rice bran.

BW - body weight; ADG - average daily gain (g/d). were indicative of the recovery of the nutritional status of beef cows still suckling their calves.

Plasma cholesterol and urea concentrations (Figure 1B, 1C) were not affected by dietary treatments $(\mathrm{P}>0.17)$, but increased at the end of the experimental period (day 22, $\mathrm{P}<0.05$ ). These changes in plasma of cholesterol and urea concentrations are probably due to the increase in the DM (Cavestany et al., 2005) and protein (Oulun, 2005) intake in both treatments as the quantity and quality of forage offered increased with the progress of the experiment. In both treatments, the observed recovery in energy balance in cows was associated with greater herbage availability and height and forage quality of natural pastures in the spring (Berreta et al., 2000; Chapman et al., 2007).

Plasma glucose concentrations (Figure 2A) did not differ between nutritional treatments or among days of experiment, but plasma glucose increased $(\mathrm{P}<0.05)$ from day 7 to day 22 only in SUP cows. The transient increase in glucose concentrations is associated with greater insulin concentrations of SUP than CON cows $(\mathrm{P}=0.04)$
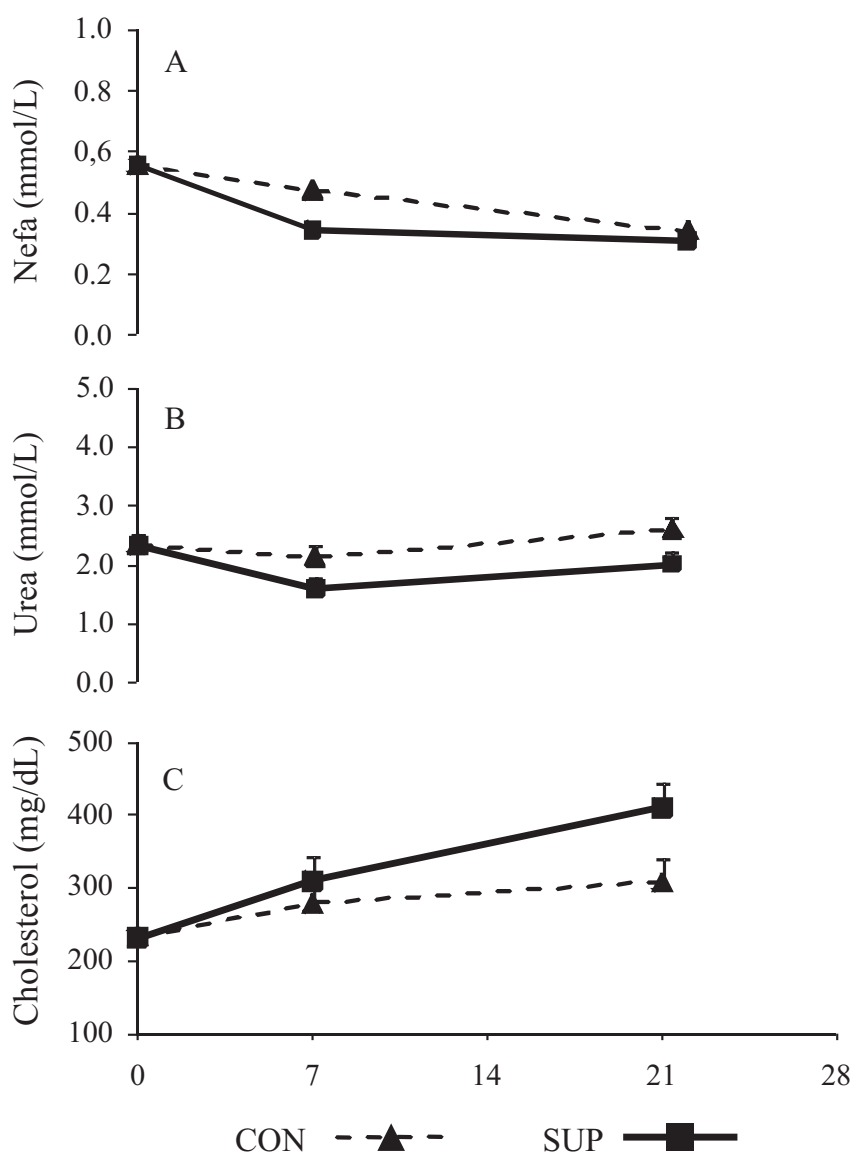

Figure 1 - Metabolite concentrations in beef cows grazing native pastures $(\mathrm{CON}, \mathrm{n}=19)$ or supplemented with whole rice bran for 21 days (SUP, $\mathrm{n}=19,2 \mathrm{~kg} / \mathrm{animal} / \mathrm{d}$ ). 
(Figure 2B), which is consistent with the observed effects of energy supplementation in dairy cows (McNamara et al., 2003; Rabelo et al., 2005; Noro et al., 2006).

It has been demonstrated that the ingestion of nutrients determines the increase in propionate precursors and other derivatives of the diet. Consequently, there is an increase in hepatic glucose synthesis rate, and thus an increase in circulating glucose concentrations (Reynolds et al., 2003). Thus, changes in circulating glucose or neoglucogenic precursor concentrations promote changes in the glucose homeostatic system (Velez \& Donkin, 2004; Karcher et al., 2007). Insulin is one of the main hormones that regulate blood concentrations of this metabolite (Coffee, 1998; Drackley et al., 2001). Insulin is synthesized by pancreatic $\beta$ cells in response to elevated glucose concentrations in blood, determining the uptake of glucose by peripheral tissues, glycogen synthesis, glycolysis and fatty acid synthesis (Coffee., 1998). Thus, greater plasma glucose and insulin concentrations due to supplementation with whole rice bran indicate a better energy balance in these animals (Rabelo et al., 2005), which could explain the earlier resumption of ovarian cyclicity (11 days). Similarly to the results of the present study, greater insulin concentrations have been observed in cows supplemented
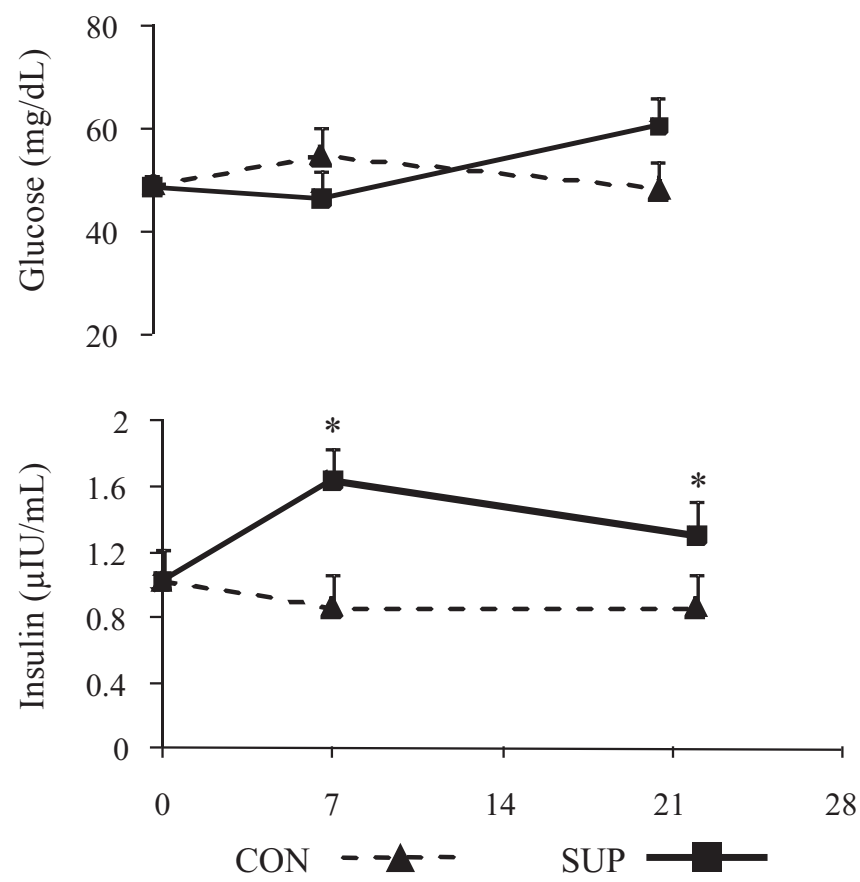

Differences between treatments are indicated with * when $\mathrm{P} \leq 0.05$.

Figure 2 - Glucose and insulin concentrations in beef cows grazing native pastures $(\mathrm{CON}, \mathrm{n}=19)$ or supplemented with whole rice bran for 21 days (SUP, $\mathrm{n}=19,2 \mathrm{~kg} /$ animal/d). during the postpartum period (for periods $>60$ days) with protein concentrates (Lents et al., 2005) or concentrates rich in lipids (Lake et al., 2006). In contrast, Astessiano et al. (2012) observed no differences in postpartum beef cows supplemented for 23 days with improved pastures. Sinclair (2008) reported a high association between circulating insulin concentrations and reproductive responses; the latter variable is responsible for the largest proportion of the variation in the interval from parturition to first ovulation (even greater than the effect of BCS at calving or postpartum energy intake).

Hepatic expression of GHR, IGF1, IGFBP2, IGFBP3, and INSR mRNA were not affected by nutritional treatments $(\mathrm{P}>0.06)$ (Table 3).

Studies addressing the effect of supplementation during the postpartum period on hepatic expression of genes in related with the somatotropic axis in beef cows are scarce in the literature. In agreement with this study, hepatic IGF1 and IGFBP3 mRNA did not change with increased frequency of supplementation with fibrous byproducts (66.67\% wheat bran, $26.93 \%$ soybean hulls, $3.75 \%$ molasses and $2.65 \%$ cotton seed flour) in multiparous beef cows during postpartum (Cooke et al., 2008). However, although they did not observe differences in hepatic IGF1 mRNA, Astessiano et al. (2012) determined reduced expression of IGFBP 3 mRNA in primiparous cows supplemented for 23 days with improved pastures during the early postpartum period (at 48 days). Astessiano et al. (2012) did not determine an effect of the nutritional treatment on hepatic IGFPB2 mRNA. It has been shown that dietary restrictions, as well as periods of negative energy balance, are associated with increased circulating concentrations of IGFBP-2 (Rajaram et al., 1997; Roberts et al., 1997). In this study, the better nutritional status of SUP than CON cows was evidenced by the observed concentrations of metabolites and insulin without changes in hepatic gene expression.

Table 3 - Hepatic expression of genes related somatotropic axis in beef cows with (SUP) or without $(\mathrm{CON})$ short-term supplementation during the pospartum ${ }^{1}$

\begin{tabular}{lcccc}
\hline & \multicolumn{4}{c}{ Nutritional treatment } \\
\cline { 2 - 5 } & CON & SUP & SE & P-value \\
\hline GHR & 3.08 & 2.50 & 0.69 & 0.56 \\
IGF1 & 0.15 & 0.12 & 0.03 & 0.50 \\
IGFBP2 & 88.77 & 44.11 & 13.94 & 0.06 \\
IGFBP3 & 6.14 & 5.93 & 1.28 & 0.91 \\
INSR & 6.09 & 4.73 & 0.88 & 0.30 \\
IGFBP3/IGFBP2 & 0.09 & 0.13 & 0.03 & 0.22
\end{tabular}

GHR - growth hormone receptor; IGF1 - insulin-like growth factor -1; IGFBP2 - IGF binding protein-2; IGFBP3 - IGF binding protein-3; INSR - insulin receptor; HPRT - hypoxanthine phosphoribosyltransferase (endogenous control).

${ }^{1}$ Control cows grazing native pastures $(\mathrm{CON}, \mathrm{n}=19)$ or supplemented (SUP, $\left.\mathrm{n}=19\right)$ for 21 days with $2 \mathrm{~kg} /$ animal/day of whole rice bran. 
Regardless of the nutritional treatment offered, GHR mRNA expression was positively associated with the expression of IGF1 mRNA $(\mathrm{P}<0.04, \mathrm{r}=0.70)$ and IGFBP3 $(\mathrm{P}<0.01, \mathrm{r}=0.62)$, thus demonstrating the effect of GH on the synthesis of IGF-I and IGFBP-3 in the liver (Sjogren et al., 1999).

The duration of postpartum anestrus was 11 days shorter in SUP than CON cows $(\mathrm{P}=0.04$, Table 4$)$, agreeing with their greater plasma cholesterol and insulin concentrations reported by several authors (Staples et al., 1998; Funston et al., 2004; Sinclair, 2008; Webb et al., 2004) and the reduced hepatic IGFBP2 mRNA expression (Roberts et al., 1997) found in these animals. However, presence of corpus luteum and pregnancy rate during the mating period did not did not differ $(\mathrm{P}>0.32)$ between experimental groups. This was probably due to the small number of animals in each treatment $(n=19)$, which did not make it possible to detect differences in binomial distributed variables because of the overlapped mean confidence intervals (Steel \& Torrie, 1992).

Contrary to the results found in this study, the duration of postpartum anestrus of beef cows was not affected by energy (Soca et al., 2008) or protein (Wetterman et al., 1986) supplementation combined or with calf temporary weaning. Also, the use of improved pastures for 23 days in suckled beef cows (at 48 days) with low BCS did not modify the duration of postpartum anestrus (Astessiano et al., 2012). In this study, despite the inhibitory effect suckling on reproduction (Hess et al., 2005) whole rice bran supplementation to primiparous cows in the second month postpartum modified nutritional/metabolic signals, allowing for an earlier resumption of ovulation (Lucy, 2003).

Table 4 - Reproductive responses of beef cows with (SUP) or without (CON) short-term supplementation during the pospartum

\begin{tabular}{|c|c|c|c|c|}
\hline & \multicolumn{4}{|c|}{ Nutritional treatment $^{1}$} \\
\hline & $\mathrm{CON}$ & SUP & SE & P-value \\
\hline Days of postpartum anestrus & $130 \mathrm{a}$ & $119 b$ & 4 & 0.04 \\
\hline \multicolumn{5}{|l|}{ Presence of corpus luteum, \% (number of cows) } \\
\hline First month of the mating period & $26(5 / 19)$ & $47(9 / 19)$ & - & 0.32 \\
\hline Second month of the mating period & $84(16 / 19)$ & $79(15 / 19)$ & & 0.68 \\
\hline End of mating the period & $95(18 / 19)$ & $84(16 / 19)$ & - & 0.38 \\
\hline Pregnancy at the end of the mating period, $\%$ (number of cows) & $84(16 / 19)$ & $79(15 / 19)$ & - & 0.81 \\
\hline
\end{tabular}

Numbers followed by different letters indicate least square means differ $(\mathrm{P} \leq 0.05)$.

SE - standard error.

${ }^{1}$ Control cows grazing native pastures $(\mathrm{CON}, \mathrm{n}=19)$ or supplemented (SUP, $\left.\mathrm{n} 19\right)$ for 21 days with $2 \mathrm{~kg} / \mathrm{animal} / \mathrm{day}$ of whole rice bran.

\section{Conclusions}

Under the conditions of this experiment, results indicated that short-term supplementation ( $<30$ days) with whole rice bran during the postpartum period increased glucose and insulin concentrations reducing the duration of postpartum anestrus. These observations were associated with cow recovery of positive energy balance and consequently with a better nutritional status

\section{References}

ALENCAR, M.M. Relação entre produção de leite da vaca e desempenho do bezerro nas raças Canchim e Nelore. Revista da Sociedade Brasileira de Zootecnia, v.18, p.146-156, 1989.

ASTESSIANO, A.L.; PÉREZ-CLARIGET, R.; QUINTANS, G. et al. Effects of a short-term increase in the nutritional plane before the mating period on metabolic and endocrine parameters. hepatic gene expression and reproduction in primiparous beef cows on grazing conditions. Journal of Animal Physiology and Animal Nutrition, v.96, p.535-544, 2012.
BAUMAN, D.E. Regulation of nutrient partitioning during lactation: homeostasis and homeorhesis revisited. In: CRONJE, P.J. (Ed.) Ruman physiology. Digestion, metabolism and growth and growth and reproduction. New York: CAB Publishing, 2000. p.311-327.

BERRETTA, E.; RISSO, D.; MONTOSSI, F. et al. Campos in Uruguay In: LEMAIRE, G; HOGDSON, J.; MORAES, A. et al. (Eds.) Grassland ecophysiology and grazing ecology. New York: $\mathrm{CAB}$ International, 2000. p.377-394.

CARRIQUIRY, M; WEBER, W.J; FAHRENKRUG, S. et al. Hepatic gene expression in multiparous Holstein cows treated with bovine somatotropin and fed 3 fatty acids in early lactation. Journal of Dairy Science, v.92, p.4889-4900, 2009.

CAVESTANY, D.J; BLANC, E.; KULCSAR, M. et al. Studies of the transition cow under a pasture-based milk production system: metabolic profiles. Journal of Veterinary Medicine, v.52. p.1-7. 2005.

CHAPMAN, D.F.; PARSONS, A.J.; COSGROVE, G.P. et al. Impacts of spatial patterns in pasture on animal grazing behavior. Intake. and performance. Crop Science, v.47, p.399-415, 2007.

CHIMONYO, M; HAMUDIKUWANA, H; KUSINA, N.T. et al. Changes in stress related plasma metabolite concentrations in working Mashona cows on dietary supplementation. Livestock Production Science, v.73, p.165-173, 2012.

COFFEE, C.J. Metabolism. Madison: Ed. Fence Creek Publishing, p.68-69, 1998. 
COOKE, R.F; ARTHINGTON, J.D.; ARAUJO, D.B. et al. Effects of supplementation frequency on performance. reproductive. and metabolic responses of Brahman crossbred females. Journal of Animal Science, v.86. p.2296-2307, 2008.

DELAHOY, J.E.; MULLER, L.D.; BARGO, F. et al. Supplemental carbohydrate sources for lactating dairy cows on pasture. Journal of Dairy Science, v.86, p.906-915, 2003.

DRACKLEY, J.K.; OVERTON, T.R.; DOUGLAS, N. et al. Adaptations of glucose and long-chain fatty acid metabolism in liver of dairy cows during the periparturient period. Journal of Dairy Science, v.84, p.100-112, 2001.

FUNSTON, R.N. Fat supplementation and reproduction in beef females. Journal of Animal Science, v.82, p.154-161, 2004.

HAWKINS, D.E.; NISWENDER, K.D.; OSS, G.M. et al. An increase in serum lipids increases luteal lipid content and alters the disappearance rate of progesterone in cows. Journal of Animal Science, v.73, p.541-545, 1995.

HESS, B.W.; LAKE, S.L.; SCHOLLJEGERDES, E.J. et al. Nutritional controls of beef cows reproduction. Journal of Dairy Science, v.83, p.90-106, 2005.

HOLNESS, D.H.; HOPLEY, J.D.H. The effects of plane of nutrition. live weight. temporary weaning and breed on the occurrence of oestrus in beef cows during the postpartum period. Animal Production, v.26, p.47-53, 1978.

KARCHER, E.L; PICKETT, M.M.; VARGA, G.A. et al. Effect of dietary carbohydrate and monensin on expression of gluconeogenic enzymes in liver of transition dairy cows. Journal of Animal Science, v.85, p.690-699, 2007.

LAKE, S.L.; SCHOLLJEGERDES, E.J.; ATKINSON, R.L. et al. Body condition score at parturition and postpartum supplemental fat effects on cow and calf performance. Journal of Animal Science, v.83, p.2908-2917, 2005.

LAKE, S.L.; SCHOLLJEGERDES, E.J.; HALLFORD, D.M. et al. Effects of body condition score at parturition and postpartum supplemental fat on metabolite and hormone concentrations of beef cows and their suckling calves. Journal of Animal Science, v.84, p.1038-1047, 2006.

LENTS, C.A.; WETTEMANN, R.P.; WHITE, F.J. et al. Influence of nutrient intake and body fat on concentrations of insulin-like growth factor-I.insulin. thyroxine. and leptin in plasma of gestating beef cows. Journal of Animal Science, v.83, p.586-596, 2005.

LUCY, M.C. Mechanisms linking nutrition and reproduction in postpartum cows. Reproduction, v.61, p.237-254, 2003.

LUCY, M.C.; VERKERK, G.A.; WHYTE, B.E. et al. Somatotropic axis components and nutrient partitioning in genetically diverse dairy cows managed under different feed allowances in a pasture system. Journal of Dairy Science, v.92. p.526-539, 2009.

McGOWAN, M.; GALLOWAY, D.; TAYLOR, E. et al. The veterinary examination of bulls. Indooroopilly, Qld: Australian Association of Cattle Veterinarians, 1995.

McNAMARA, S.; MURPHY, J.J.; RATH, M. et al. Effects of different transition diets on energy balance. blood metabolites and reproductive performance in dairy cows. Livestock Production Science, v.84. p.195-206, 2003.

MEIKLE, A.; KULCSAR, M.; CHILLIARD, Y. et al. Effects of parity and body condition at parturition on endocrine and reproductive parameters of the cow. Reproduction, v.127, p.727-737, 2004.

MOORE, J.E.; BRANT, M.H.; KUNKLE, W.E. et al. Effects of Supplementation on voluntary forage intake, diet digestibility and animal performance. Journal of Animal Science, v.77, Suppl. 2, p.122-135, 1999.

MULLINIKS, J.T.; KEMP, M.E.; VALVERDE-SAENZ, S.I. et al. Impact of supplemented glucogenic precursors on nutrient partitioning in young postpartum range cows. Proceedings. Western Section. American Society of Animal Science, v.59, p.391-395, 2008.

NDLOVU, T.; CHIMONYO, M.; OKOH, A.I. et al. Assessing the nutritional status of beef cattle: current practices and future prospects. African Journal of Biotechnology, v.6, p.2727-2734, 2007.
NORO, M.; VARGAS, V.; PULIDO, R.G. et al. Effects of two type of concentrate on energy and protein blood metabolites in grazing dairy cows during spring. Archivos Médicos Veterinarios, v.38, p.227-323, 2006.

NOTTLE, M.B.; KLEEMANN, D.O.; SEAMARK, R.F. Effect of previous undernutrition on the ovulation rate of merino ewes supplemented with lupin grain. Animal Reproduction Science, v.49, p.29-36, 1997.

OULUN, Y. Variation in the blood chemical constituents of reindeer. significance of season. nutrition and other extrinsic and intrinsic factors. Acta Univesitatis Ouluensis. Scientiae Rerum Naturalium, A440, 2005.

PÉREZ-CLARIGET, R.; CARRIQUIRY, M.; SOCA, P. Estrategias de manejo nutricional para mejorar la reproducción en ganado bovino. Archivos Latinoamericanos de Producción Animal, v.15, p.114-119, 2007.

RABELO, E.; REZENDE, R.L; BERTICS, S.J. et al. Effects of preand postfresh transition diets varying in dietary energy density on metabolic status of periparturient dairy cows. Journal of Dairy Science, v.88, p.4375-4383, 2005.

RAJARAM, S.; BAYLINK, D.J.; MOHAN, S. Insulin-like growth factor-binding proteins in serum and other biological fluids: regulation and functions. Endocrine Reviews, v.18, p.801-831, 1997.

REYNOLDS, C.K.; AIKMAN, P.C.; LUPOLI, B. et al. Splanchnic metabolism of dairy cows during the transition from late gestation through early lactation. Journal of Dairy Science, v.86, p.1201-1217, 2003.

ROBERTS, A.J.; NUGENT, R.A.; KLINDT, J. et al. Circulating insulin-like growth factor i, insulin-like growth factor binding proteins, growth hormone and resumption of estrus in postpartum cows subjected to dietary energy restriction. Journal of Animal Science, v.75, p.1909-1917, 1997.

ROMÁN, L.; CLARIGET, J.M.; KARLEN, M. et al. Efecto de la suplementación con glicerina cruda y afrechillo de arroz sobre el comportamiento productivo y reproductivo de vacas de carne. Jornadas Uruguayas de Buiatría, p.235-236, 2011.

SHORT, R.E.; BELLOWS, R.A.; STAIGMILLER, R.B. et al. Physiological mechanisms controlling anestrous and infertility in postpartum beef cattle. Journal of Animal Science, v.68, p.799-816, 1990.

SINCLAIR, K.D. Lactational anoestrus in cattle: lessons from the suckled beef cow. Cattle Practice, v.16, p.24-31, 2008.

SJOGREN, K.; LIU, J.L.; BLAD, K. et al. Liverderived insulin-like growth factor I (IGF-I) is the principal source of IGF-I in blood but is not required for postnatal body growth in mice. Proceedings of the National Academy of Sciences of the United States of America, v.96, p.7088-7092, 1999.

SMIT, H.J.; TAWEEL, H.Z.; TAS, B.M. et al. Comparison of techniques for estimating herbage intake of grazing dairy cows. Journal of Dairy Science, v.88, p.1827-1836, 2005.

SOCA, P.; OLMOS, F.; ESPASANDÍN, A. et al. Herramientas para mejorar la utilización del campo natural. el ingreso económico de la cría y atenuar los efectos de la variabilidad climática en sistemas de cría vacuna del Uruguay. a - impacto en cambios en la estrategia de asignación de forraje sobre la productividad de diversos grupos genéticos bajo pastoreo del campo natural. Serie Técnica INIA, v.174, p.110-120, 2008

SOCA, P.M.; CLARAMUNT, M.; DO CARMO, M. Sistemas de cría vacuna en ganadería pastoril sobre campo nativo sin subsidios: Propuesta tecnológica para estabilizar la producción de terneros con intervenciones de bajo costo y de fácil implementación. Revista Ciencia Animal, v.3, p.3-22, 2007.

STAPLES, C.R.; BURKE, J.M.; THATCHER, W.W. Influence of supplemental fats on reproductive tissues and performance of lactating cows. Journal of Dairy Science, v.81, p.856-871, 1998.

STEEL, R.G.D.; TORRIE, J.H. Bioestadística. Principios y procedimientos. México: Editorial Graf América, 1992. 622p. 
VELEZ, J.C.; DONKIN, S.S. Bovine somatotropin increases hepatic phosphoenolpyruvate carboxykinase mRNA in lactating dairy cows. Journal of Dairy Science, v.87, p.1325-1335, 2004.

VIZCARRA, J.A.; IBAÑEZ, W.; ORCASBERRO, R. Repetibilidad y reproducibilidad de dos escalas para estimar la condición corporal de vacas Hereford. Investigaciones Agronómicas, v.7, p.45-47, 1986.
WEBB, R.; GARNSWORTHY, P.C.; GONG, J.G. et al. Control of follicular growth: Local interactions and nutritional influences. Journal of Animal Science, v.82, p.63-74, 2004.

WETTEMANN, R.P.; HILL, G.M.; BOYD, M.E. et al. Reproductive performance of postpartum beef cows after short-term calf separation and dietary energy and protein supplementation. Theriogenology, v.4. p.433-43, 1986. 